УДК 347

DOI https://doi.org/10.15421/391989

\author{
Щербина Є. М., \\ кандидат юридичних наук, дочент, \\ доцент кафедри ичивільного, трудового та господарського права \\ Дніпровського начіонального університету імені Олеся Гончара
}

\title{
ЮРИДИЧНІ ШЛЯХИ БОРОТЬБИ З ІНФОРМАЦЙНИМ РЕЙДЕРСТВОМ В УКРАЇНІ
}

\section{LEGAL WAYS TO COMBAT INFORMATION RARE IN UKRAINE}

У статті досліджується проблема існування інформаційного рейдерства в Україні, юридичні шляхи подолання (мінімізації шкоди) інформаційного рейдерства в сучасних реаліях.

В епоху інформаційних технологій все більш актуальним стає питання захисту своєї інформації та інформації про себе у їі первісному вигляді. І це стосується не лише певних особистих даних, а й відомостей про ділову репутацію юридичної особи. Зараз питання захисту ділової репутації юридичних осіб стає нагальним через зловживання певними зацікавленими громадянами своїми правами на висловлення «власної думки». Основною проблемою, яка буде розглянута у цій статті, $є$ винайдення шляхів юридичної протидії так званому «інформаційному рейдерству», розгляд варіантів судового та позасудового захисту порушеного права.

Актуальність даної теми полягає в тому, що інформаційне рейдерство чинить перешкоди нормальній господарській діяльності великої кількості підприємств реального сектору економіки, і шляхи його подолання або хоча б мінімізації шкідливого впливу допоможуть юридичним особам не гальмувати свою діяльність та максимально швидко відновлювати свою високу працездатність.

Інформаційне рейдерство глибоко проникло в сучасні реалії українського суспільства. Корумпованість влади, недосконалість вітчизняного законодавства та небажання органів місцевого самоврядування вчиняти активні дії із захисту свої основних платників податків - юридичних осіб є сприятливим середовищем для поширення та ще більшого укорінення таких агресивних нападок на український бізнес. Лише чітке законодавче врегулювання, скоординована та відлагоджена робота представників юридичних осіб, органів виконавчої влади, місцевого самоврядування та небайдужих громадян може побороти таке негативне явище. Викорінення інформаційного рейдерства буде сприяти поліпшенню економічного та інвестиційного клімату в країні, що призведе до неминучого покращення рівня життя населення.

Ключові слова: юридична особа, інформація, захист інформації, ділова репутація, захист ділової репутації.

In the article the problem of existence of informative corporate raid is investigated in Ukraine, legal ways of overcoming (minimizations of harm) of informative corporate raid in modern realities.

In the epoch of information technologies the question of defence of the information and information becomes all more actual about itself in her primitive kind. And it touches not only the certain personal data but also information of пр business reputation of legal entity. Now the question of defence of business reputation of legal entities becomes urgent, through abuse of the certain interested citizens by the rights on offering a "own opinion". By a basic problem, that will be considered in the real article there is an invention of ways of legal counteraction to the socalled "informative corporate raid", consideration of variants of judicial and extrajudicial defence of the broken right.

Actuality of this theme consists in that an informative corporate raid does obstacle to normal economic activity of plenty of enterprises real to the sector of economy and ways of his overcoming or even.

An informative corporate raid deeply got to modern realities of Ukrainian societ. Corrupted of power, to accomplish imperfection of home legislation and not desire of organs of local selfgovernment active operating under defence it basic taxpayers legal entities is a favourable environment for distribution and greater taking root of such aggressive verbal attacks Ukrainian business. Only clear legislative settlement, and the debugged work of representatives of legal entities, executive, local selfovernment and unindifferent citizens bodies can overcome such negative phenomenon. Eradication of informative corporate raid will assist the improvement of economic and investment climate in a country that will result in the inevitable improvement of standard of livingorate raid will assist the improvement of economic and investment climate in a country that will result in the inevitable improvement of standard of living.

Key words: legal entity, information, priv, business reputation, defence of business reputation.

Постановка проблеми та її актуальність. Сьогодні, в епоху інформаційних технологій, все більш актуальним стає питання захисту своєї інформації та інформації про себе в іiі первісному вигляді. I це стосується не лише певних особистих даних, а й відомостей про, наприклад, ділову репутацію юридичної особи. Зараз питання захисту ділової репутації юридичних осіб стає нагальним через зловживання певними зацікавленими громадянами своїми правами на висловлення «власної думки». Основною проблемою, яка буде розглянута у цій статті, є винайдення шляхів юридичної протидії так званому «інформаційному рейдерству», роз- гляд варіантів судового та позасудового захисту порушеного права.

Актуальність даної теми полягає в тому, що інформаційне рейдерство чинить перешкоди нормальній господарській діяльності великої кількості підприємств реального сектору економіки, і шляхи його подолання або хоча б мінімізації шкідливого впливу допоможуть юридичним особам не гальмувати свою діяльність та максимально швидко відновлювати свою високу працездатність.

Стан дослідження. Дослідженням суміжної до інформаційного рейдерства тематики займалися такі наукові діячі, як Черевко О.В., Таращанська 
О.Б., Юрченко О.М. Однак особливу увагу під час розроблення шляхів боротьби з інформаційним рейдерством варто звернути на доробки практикуючих юристів - Попкової Г., Сегіди Г.

Метою статті $\epsilon$ пошук юридичних та неюридичних шляхів боротьби з інформаційним рейдерством.

Виклад основного матеріалу. Конституцією України кожному гарантується право на свободу думки і слова, на вільне вираження своїх поглядів і переконань (стаття 34). Разом із тим відповідно до статті 68 Конституції України кожен зобов'язаний неухильно додержуватися Конституції та законів України, не посягати на права і свободи, честь і гідність інших людей. Праву на свободу думки і слова, на вільне вираження своїх поглядів і переконань відповідає обов'язок не поширювати про особу недостовірну інформацію та таку, що ганьбить ії гідність, честь чи ділову репутацію [7].

Існує багато різних визначень рейдерства, але всіх їх поєднує те, що «рейдерство» - це завжди недружнє поглинання або навіть захоплення. Ставлення до нього в більшості країн неоднозначне і часто негативне [6].

Інформаційне рейдерство - це порівняно новий i не характерний раніше різновид рейдерства для України і країн СНД. За своєю моделлю воно нагадує «П'яту хвилю» рейдерства в США, де рейдер здатний за допомогою тактичних прийомів «розгойдування» механізму оперативного управління діяльністю компанії поглинати компанії-жертви [6].

Важливо відрізняти напрямки рейдерства в різних країнах. У країнах із розвинутою ринковою економікою інформаційне рейдерство спрямоване на зниження вартості акцій компаній-жертв із подальшим їх поглинанням та розпродажем їхнього майна, активів, тощо. Самі рейдери вважають свою діяльність корисною для економіки, оскільки «чистка» слабких підприємств на законних підставах підвищує ефективність бізнесу. Скупка великих пакетів акцій неефективних компаній служить тому, щоб повалити топ-менеджмент, скоротити непродуктивні витрати, продати зайві підрозділи і в підсумку підняти ціни на акції [6].

Однак в економічно-слабких, мало розвинутих та корумпованих країнах, до яких відноситься Україна, головною метою інформаційного рейдерства $€$ блокування роботи компанії-жертви, зниження іiі собівартості та/або вартості продукції, робіт та послуг, які воно надає, створення негативної суспільної думки стосовно даного підприємства, зменшення клієнтської бази, отримання неправомірної вигоди за припинення такої агресивної діяльності тощо. На жаль, у нашій країні такі дії здійснюються для захоплення компаній-жертв за мізерними цінами, отримання «відкупних» за спокійну працю та як метод боротьби 3 конкуренцією на ринку. Українське рейдерство - це в основному протизаконний, корупційний перерозподіл власності, а не процес економічної оптимізації [6].

Таким чином, у наших реаліях інформаційне рейдерство являє собою діяльність, спрямовану на агресивне захоплення, паралізацію діяльності та паплюження ділової репутації компанії-жертви за для дискредитування іiї та її товарів на ринку.

Шляхів для здійснення інформаційного рейдерства достатньо у сучасному суспільстві, де кожна людина щохвилини, безперервно сприймає інформацію. Найпоширенішими в Україні є:

1) поширення недостовірної інформації в мережі Інтернет про саму компанію, iї методи роботи, організацію тощо;

2) залишення так званих «фейкових» відгуків негативного характеру про роботу компанії та/або про іiі товари, що можуть не відповідати дійсності та бути написаними зовсім не споживачами товарів/ або послуг, які надаються компанією;

3) демонстрації з плакатами, гаслами і т.д., що паплюжать ділову репутацію компанії та перешкоджають її роботі.

Усі ці методи спрямовані на знівечення статусу та ділової репутації компанії. Безперечно, це не $€$ «рейдерством» у класичному для більшості розумінні - не є силовим захопленням адміністративних будівель (приміщень) підприємства. Однак мету носить одну й ту саму - недружнє поглинання за найнижчою вартістю та/або агресивну боротьбу з конкурентами.

Таким чином, боротьба з інформаційним рейдерством балансує на стику прав двох протидіючих у цій ситуації сторін: права збиратися мирно, без зброї і проводити збори, мітинги, походи і демонстрації, права на свободу думки і слова, на вільне вираження своїх поглядів і переконань - з одного боку, та права на недоторканність ділової репутації юридичної особи - 3 іншого.

Так, статтею 94 Цивільного кодексу України визначено, що «юридична особа має право на недоторканність її ділової репутації, на таємницю кореспонденції, на інформацію та інші особисті немайнові права, які можуть їй належати» [11].

Відповідно до ст. 201 Цивільного кодексу України ділова репутація юридичної особи є немайновим благом [11].

Особисті немайнові права юридичної особи захищаються відповідно до глави 3 цього Кодексу та включають в себе як судовий, так і позасудовий порядок захисту.

Оскільки способів порушення законного права юридичних осіб на недоторканість ділової репутації існує безліч, вони відносяться до різноманітних галузей суспільного життя тощо, вважаємо за необхідне сконцентрувати свою увагу на шляхах протидії поширенню недостовірної інформації та паплюженню ділової репутації шляхом мітингів, демонстрацій, гасел тощо, бо саме цей спосіб може не тільки похитнути діловий імідж, а й фактично перешкоджати нормальній роботі підприемства.

Ст. 39 Конституції України надає громадянам право збиратися мирно, без зброї і проводити збори, мітинги, походи і демонстрації, про проведення яких завчасно сповіщаються органи виконавчої влади чи органи місцевого самоврядування [4].

У ч. 1 ст. 20 Загальної декларації прав людини встановлено, що «кожна людина має право на сво- 
боду мирних зібрань», так само як і у ст. 21 Міжнародного пакту про громадянські і політичні права визначено право на мирні зібрання.

Обмеження щодо реалізації цього права може встановлюватися судом відповідно до закону і лише в інтересах національної безпеки та громадського порядку - з метою запобігання заворушенням чи злочинам, для охорони здоров'я населення або захисту прав і свобод інших людей [4].

На жаль, у законі чітко не прописана необхідність захисту прав не лише громадян - фізичних осіб, а й юридичних осіб, чиї права теж безумовно порушуються. Тому дії 3 юридичного обмеження у проведенні таких негативних і агресивних відносно юридичних осіб заходів можуть здійснюватися лише $з$ міркувань збереження громадського порядку та охорони прав саме фізичних осіб.

Широкі повноваження громадян у сфері масових публічних зібрань можуть приводити до зловживання 3 корисливою метою своїми правами та порушенням прав інших осіб.

Зараз таке свавілля стає все більш і більш популярним. Нерідко можна побачити мітингуючих поряд із якоюсь адміністративною будівлею, підприємством, банком тощо, які виголошують гучні негативні гасла стосовно юридичної роботи, їі керівників або співробітників, або безперервною колоною переходять через пішохідний перехід із плакатами, тим самим блокуючи проїзд автомобільного транспорту до підприємства, установи, організації, а отже, й повноцінне його функціонування.

Насправді така ситуація є доволі руйнівною для ділової репутації юридичної особи-жертви та організації роботи взагалі. Пішоходи, що проходять повз, не розбираються в ситуації та у правдивості вигуків і написаних текстів, вони просто сприймають інформацію і формують у себе та серед своїх знайомих негативну суспільну думку. Такі дії призводять до доволі болючого удару по іміджу компанії та по формуванню клієнтської бази, що є інформаційним нападом на юридичну особу.

Слід констатувати, що чинне законодавство 3 питань організації і проведення мирних заходів $\epsilon$ недосконалим. Раніше діяла спеціальна норма, яка регулювала порядок проведення масових зібрань. Однак Указ Президії Верховної Ради СРСР «Про порядок організації і проведення зібрань, мітингів, вуличних походів і демонстрацій в СРСР» від 28.07.1988 року був визнаний неконституційним [10].

Однак, на щастя, згідно з п. 1. розділу XV «Перехідні положення» Конституції України він діє в частині, що не суперечить Конституції України, в тому числі щодо того, що про проведення мирних зборів, мітингів, походів і демонстрацій повинні бути завчасно повідомлені органи виконавчої влади та місцевого самоврядування [4]. Зазначеним Указом також визначено, зокрема, осіб, уповноважених звертатися до виконавчих органів сільських, селищних, міських рад із повідомленням про проведення мирного заходу, вимоги до змісту такого повідомлення, вимоги щодо забезпечення виконавчими органа- ми сільських, селищних, міських рад умов проведення мирного заходу тощо [5].

Таким чином, мітингарі повинні повідомляти органи виконавчої влади та місцевого самоврядування про свої наміри провести такий захід. Це здійснюється задля можливості органів влади забезпечити дотримання правопорядку на цьому заході.

Відповідно до Указу Президії Верховної Ради СРСР «Про порядок організації і проведення зібрань, мітингів, вуличних походів і демонстрацій в СРСР» від 28.07.1988 року «заява про проведення зборів, мітингу, вуличного походу або демонстрації подається в письмовій формі не пізніш як за десять днів до намічуваної дати їх проведення. У заяві зазначаються мета, форма, місце проведення заходу або маршрути руху, час його початку і закінчення, передбачувана кількість учасників, прізвища, імена, по батькові уповноважених (організаторів), місце їх проживання і роботи (навчання), дата подачі заяви» [10].

Оскільки відповідно до Конституції України має забезпечуватись суспільна безпека та непорушення прав інших осіб, то саме ця норма і $є$ відносно рятівною для юридичних осіб-жертв.

Так, відповідно до ст. 280 Кодексу адміністративного судочинства України органи виконавчої влади, органи місцевого самоврядування негайно після одержання повідомлення про проведення зборів, мітингів, походів, демонстрацій тощо мають право звернутися до окружного адміністративного суду за своїм місцезнаходженням із позовною заявою про заборону таких заходів чи про встановлення іншого обмеження права на свободу мирних зібрань (щодо місця чи часу їх проведення тощо) [3].

Органам місцевого самоврядування пп. 3 п. Б ч. 1 ст. 38 Закону України «Про місцеве самоврядування в Україні» надана можливість вирішення відповідно до закону питань про проведення зборів, мітингів, маніфестацій і демонстрацій, спортивних, видовищних та інших масових заходів; здійснення контролю за забезпеченням під час їх проведення громадського порядку [2].

Позивач повинен обгрунтувати необхідність встановлення обмеження щодо реалізації права на свободу мирних зібрань у демократичному суспільстві та пропорційність запропонованого в позові способу обмеження. [3]

Суд задовольняє вимоги позивача в інтересах національної безпеки та громадського порядку в разі, якщо визнає, що проведення зборів, мітингів, походів, демонстрацій чи інших зібрань може створити реальну небезпеку заворушень чи вчинення кримінальних правопорушень, загрозу здоров'ю населення або правам і свободам інших людей [3].

Таким чином, якщо органи виконавчої влади або місцевого самоврядування будуть відповідально відноситись до нагляду за проведенням масових зібрань, то буде можливість уникнути протиправної діяльності стосовно паплюження ділової репутації українських компаній.

Однак, хоч і в меншої кількості перехожих, все одно залишаться неприємні відголоски, які будуть 
сприйматися більш ніж серйозно. Проте можливе застосування нестандартних підходів боротьби 3 проникненням негативної неправдивої інформації у свідомість пересічних громадян. Один із таких способів був запропонований на спільному засіданні Правового комітету та Комітету з маркетингу та комунікацій Свропейської Бізнес Асоціації у Дніпрі на тему «Протидія інформаційному рейдерству та нестандартні підходи до вирішення проблеми».

Так, представники одного з банків Дніпропетровщини проводили боротьбу з таким «чорним піаром» відносно своєї компанії маркетинговим шляхом. Ним були прийняті заходи для дискредитації негативної кампанії мітингарів шляхом переведення їх акції у жарт. До пікетувальників вони запросили групу аніматорів у костюмах клоунів та увімкнули на фоні музику з дитячих мультфільмів.

Хоча цей метод $є$ зовсім не юридичним та не може стовідсотково уберегти юридичну особу від паплюження іiі ділової репутації, він допоможе принаймні не акцентувати увагу перехожих на негативних гаслах і написах, сприймати дане скупчення людей як щось несерйозне або просто посміхнутися і піти далі.

Висновок. Підсумовуючи, можна сказати, що інформаційне рейдерство глибоко проникло в сучасні реалії українського суспільства. Корумпованість влади, недосконалість вітчизняного законодавства та небажання органів місцевого самоврядування вчиняти активні дії із захисту своїх основних платників податків - юридичних осіб є сприятливим середовищем для поширення та ще більшого укорінення таких агресивних нападок на український бізнес. Лише чітке законодавче врегулювання, скоординована та відлагоджена робота представників юридичних осіб, органів виконавчої влади, місцевого самоврядування та небайдужих громадян може побороти таке негативне явище. Викорінення інформаційного рейдерства буде сприяти поліпшенню економічного та інвестиційного клімату в країні, що призведе до неминучого покращення рівня життя населення.

\section{ЛІТЕРАТУРА:}

1. Виступ Попкова Г.В. засіданні маркетингового і правового комітетів EBA Dnipro - Dnipro Office of European Business Association на тему Протидія інформаційному рейдерству 24.09.2018 рік. Європейська Бізнес Асойіація. URL : https://eba.com.ua/protydiya-informatsijnomu-rejderstvu-ta-nestandartni-pidhody-do-vyrishennya-problemy/.

2. Закону України «Про місцеве самоврядування в Україні» 3 останніми змінами та доповненнями. Редакція від 04.11.2018 / Верховна Рада України. Офіційний веб-сайт. Управління комп’ютеризованих систем Апарату Верховної ради України () 1994-2018. URL : http://zakon.rada.gov.ua/laws/show/280/97-\%D0\%B2\%D1\%80.

3. Кодекс адміністративного судочинства України з останніми змінами та доповненнями. Редакція від 04.11.2018 / Верховна Рада України. Офіційний веб-сайт. Управління комп’ютеризованих систем Апарату Верховної ради України ( 1994-2018. URL : http://zakon.rada.gov.ua/laws/show/2747-15\#n12675.

4. Конституція України. 3 останніми змінами та доповненнями. Редакція від 30.09.2016 / Верховна Рада України. Офіційний веб-сайт. Управління комп’ютеризованих систем Апарату Верховної ради України (C 1994-2018. URL: http://zakon3.rada.gov.ua/ laws/show/254к/96-вр.

5. Лист Міністерства юстиції України № 1823-0-1-09-18 від 26.11.2009 / Верховна Рада України. Офіційний веб-сайт. Управління комп'ютеризованих систем Апарату Верховної ради України (C 1994-2018. URL : http://zakon.rada.gov.ua/laws/ show/v823-323-09.

6. Мартынюк Н. Рейдерство: причины, классификация, защита. Лига Закон. 2012. URL : https:/jurliga.ligazakon.net/ analitycs/59788_reyderstvo-prichiny-klassifikatsiya-zashchita.

7. Постанова Пленуму Верховного Суду України № 1 від 27.02.2009 Про судову практику у справах про захист гідності та честі фізичної особи, а також ділової репутації фізичної та юридичної особи / Верховна Рада України. Офіційний вебсайт. Управління компютаризованих систем Апарату Верховної ради України (C 1994-2018. URL : http://zakon.rada.gov.ua/ laws/show/v 001700-09.

8. Сегида Г. Рейдерство: что это такое и как происходят захваты бизнеса. (C) 200-2018. ЛIГАБізнесІнформ. 2016. URL : https://blog.liga.net/user/gsegida/article/23958.

9. Таращанська О.Б. Рейдерство в Україні: причини виникнення та шляхи подолання. Інвестиції: практика та досвід. № 2. 2011. URL : http://www.irbis-nbuv.gov.ua/cgi-bin/irbis_nbuv/cgiirbis_64.exe?C21COM=2\&I21DBN=UJRN\&P21DBN=UJRN\& IMAGE_FILE_DOWNLOAD=1\&Image_file_name=PDF/ipd_2011_2_32.pdf.

10. Указ Президії Верховної Ради СРСР Про порядок організації і проведення зборів, мітингів, вуличних походів і демонстрацій в СРСР / Верховна Рада України. Офіційний веб-сайт. Управління комп'ютеризованих систем Апарату Верховної ради України (C) 1994-2018. URL : http://zakon.rada.gov.ua/laws/show/v9306400-88.

11. Цивільний кодекс України 3 останніми змінами та доповненнями. Редакція від 04.11.2018 / Верховна Рада України. Офіційний веб-сайт. Управління комп’ютеризованих систем Апарату Верховної ради України (C) 1994-2018. URL : http://zakon.rada.gov.ua/laws/show/435-15\#n11.

12. Черевко О.В. Рейдерство як одна з серйозних загроз економічній безпеці підприємства. Ефективна економіка. № 12. 2013. URL : http://www.economy.nayka.com.ua/?op=1\&z=3308.

13. Юрченко О.М. Рейдерство в Україні. Боротьба з організованою злочинністю і корупщією (теорія і практика). № 2(28). 2012. URL : http://www.irbis-nbuv.gov.ua/cgibin/irbis_nbuv/cgiirbis_64.exe?C21COM=2\&I21DBN=UJRN\&P21DBN=UJRN\&IM AGE_FILE_DOWNLOAD=1\&Image_file_name=PDF/boz_2012_2_12.pdf. 